UNRAM Law Review is licensed under a Creative Commons Attribution 4.0 International License, which permits unrestricted use, distribution, and reproduction in any medium, provided the original work is properly cited. p-ISSN: 2548-9267 | e-ISSN : 2549-2365, Open Access at : http://unramlawreview.unram.ac.id/index.php/ulr

\begin{tabular}{c|c|c|c|c|}
\hline Volume & Issue & Page & April & p-ISSN: 2548-9267 \\
\hline 3 & 1 & $54-63$ & 2019 & e-ISSN : 2549-2365
\end{tabular}

\title{
Direction of National Law Development Year 2005-2025 to Encounter the Age of 4.0 Industry Revolution
}

\author{
Prandy A.L Fanggi \\ Program Studi Magister Ilmu Hukum Program Pascasarjana \\ Universitas Mataram \\ Email : prandyarts@gmail.com \\ Safaruddin Efendi \\ Program Studi Magister Ilmu Hukum Program Pascasarjana \\ Universitas Mataram \\ Email :saparudinefendi94@gmail.com \\ Rengga Sandi Suranggana \\ Program Studi Magister Ilmu Hukum Program Pascasarjana \\ Universitas Mataram \\ Email :rengga_sandi@yahoo.com \\ Rosadi Purwohadi \\ Program Studi Magister Ilmu Hukum Program Pascasarjana \\ Universitas Mataram \\ Email : rosadipurwahadi@gmail.com
}

\begin{abstract}
Aim of this research is to analyze the direction of national legal development in the period of 2005-2025 in order to address 4.0 industry revolution era. This research is applying normative research method and conceptual approach by mean of studying legal concept and theory supplemented with statute approach in order to analyze legal regulations related to this research. According to research result, national legal development 2005-2025 was not prepared to tackle 4.0 industry revolution era, since the direction national legal development substantially is not compatible and not comprehensive as legal development is positioned as the booster of national economy advancement in long-term development plan of 2005-2025.
\end{abstract}

Keywords: Development, legal, revolution, industry

\section{INTRODUCTION}

One of social development that requires legal adaptation is the field of modern technology and medical. Reflecting the phenomena of people's life in the end of twentieth century, it is clear that modern technology has started to dominate men's life. ${ }^{1}$ The ancestor took thousands year to conduct experiment on life tools' inventions. It also needed thousands year for mankind to reach the point of maximum potential development which is known as industry revolution,

\footnotetext{
${ }^{1}$ Satcipto rahardjo.(2014) , Ilmu Hukum, PT Citra Aditya Bakti, cetakan kedelapan, Bandung,. hlm. 206
} 
a synonym of machine century. Since then, mankind history altered in many aspects such as power, ability, speed, efficiency etc. ${ }^{2}$

The term of industry revolution initially declared by Arnold Toynbee in his book "lectures on the industrial revolution" which described Industry revolution and its impact toward policy, production mechanism, culture and world's financial order particularly in the European. The revolution triggered by the invention of steam engine by James Watt. Further, industry revolution 2.0 benchmarked by the invention of electrical power and industry revolution 3.0 was flagged by the invention of computer. In the early $21^{\text {st }}$ century, invention of Internet and information technology (IT) triggered the conceived of 4.0 revolution. ${ }^{3}$

The emerging of steam engine in the $18^{\text {th }}$ century has managed to significantly accelerate economy as within two century it has increased income per capita countries worldwide to six fold. Second industry revolution known as technology revolution, this revolution marked with the use and production of iron and steel in massive scale, spread of steam power and telegraph machine. Besides, crude oil was started to discover and used widely as well as the early period of electric power usage. ${ }^{4}$

In the third revolution, manufacture industry altered to be digital businesses. Digital technology has dominated media and retail industry. This third revolution has change relation and communication pattern in contemporary society. It has shortened distance and time since such a revolution promoting aspects of real time. Giant leap occurred of industrial sector occur in the era of fourth revolution where information technology and communication is fully utilized. Business model also experienced major change, not only in term of production process but also in term of whole industry value chain. ${ }^{5}$

John Pieris mentioned a number of 4.0 industry revolution character as a new civilization. It has 4 characters, namely (1) simplicity or compact and anti-complexity; previously, one tool is used for one specific task, today through android technology one tool can be used for many tasks from texting, Internet or even gaming. (2) Faster means anytime, anywhere and stateless; previously to study in overseas university such as Harvard someone must travel and stay at the United State, today registration can be conducted via website; cheaper and (4) accessible means that access is information asset. ${ }^{6}$

The world is facing the fourth industrial change or what is so called industry 4.0. This fourth industry revolution is characterized by artificial intelligence, super computer, genetic engineer, nano technology, automatic car and innovation. Changes occurred in an exponential speed which affected to economy, industry, governance and politic. It is getting more obvious that the world today has become a global village. ${ }^{7}$

According to Mc Kinsey global institute analysis, industry 4.0 brought massive and wide impacts mainly in labor sector since robot and machine eradicate numbers of working field worldwide. Therefore, this revolution shall be address wisely and carefully by business actors. ${ }^{8}$

On the one side, the industry revolution through its connectivity and digitalization managed to increase efficiency of manufacture chain and product quality. However, on the other side this situation potentially will erase approximately 800 million jobs around the world in 2030 since

\footnotetext{
${ }^{2}$ Ibid. P. 209

${ }^{3}$ Papar Prof. Dr. John Pieris, SH, MS, alumnus S3 hukum di Universitas Indonesia (UI) tahun 2003, Dosen Program PascasarjanaUniversitas Kristen Indonesia (UKI)kepada Staging-Point.Com, Rabu (7/11/2018) di AulaGedungPascasarjana UKI, Jakarta.Diakses lewat:http://www.stagingpoint.com/read/2018/11/14/151205/Kecerdasan.Hukum.Respons.Revolusi. Industri.4.0

${ }^{4}$ Venti Eka Satya.(2018 )Strategi Indonesia Menghadapi Industri 4.0,Info Singkat Vol. X No. 9/I/Puslit/Mei/2018, Pusat Penelitian Badan Keahlian DPR-RI, Jakarta,p. 20

${ }^{5}$ Ibid.

${ }^{6}$ Ibid.

${ }^{7}$ Ibid.

${ }^{8}$ Loc.cit. Venti Eka Satya
} 
it undertaken by robots. Therefore, it can threat for Indonesia as a country with high percentage of labor force and unemployment. ${ }^{9}$

Lawgeek, an artificial intelligence (AI) developer company of the United State has arranged a competition between their AI product and 20 top US lawyers of well-known law firm such as K\&L Gates, Goldman Sachs, Alston \& Bird and Cisco. The result shown that the 20 top US lawyer consist of associate, in-house, single practitioner and general counsel only managed to complete 5 documents review NDAs with average speed of 92 minutes and 85 percent of accuracy level. ${ }^{10}$

It recorded best performance of human lawyer took 51 minutes and 91 percent of accurate level, meanwhile worst performance sit in 67 percent of accuracy level. Whereas, AI designed by Lawgeek only took 26 second with 94 accurate level to review 5 NDA's documents. Moreover, in the US today there is another "digital lawyer" named "Ross Intelligence" who claimed as world's best AI. Only by spend a few dollars per month, someone can have legal assistant by robot who can carry out speedy research and analysis with around 97 percent accuracy.

4.0 industry as a technology revolution stage altered mankind activities pattern in term of scale, scope, complexity and transformation of previous life experience. Mankind is predicted will live in global uncertainty, hence mankind must obtain ability to predict the dynamic future. Every country must be able to respond the change in an integrated and comprehensive manner. The respond shall involve all stakeholders of global politic including public and private sector, academics and civil society in order to maintain 4.0 industry's challenge become opportunities. ${ }^{11}$ Wolter identified 4.0 industry's challenge as follows:

1) Issue on the security of information technology;

2) Reliability and stability of production machine;

3) Lack of adequate skill;

4) Reluctance of the stakeholders to embrace changes; and

5) disappearance of jobs due to automation ${ }^{12}$

Noticing the impact of 4.0 industry revolution that has occurred in the society, I intend to study readiness of national development plan 2005-2025 to address technology advancement challenge in the era of 4.0 industry revolution by analyzing problem as follows: what is national legal development concept of 2005-2025 and what is the ideal national legal development concept to face the era of 4.0 industry revolution.

\section{ANALYSIS AND DISCUSSION}

\section{Analysis On Long Term Development Plan Concept 2005-2025}

\section{Economic Development As The Foundation Of National Development 2005-2025}

Throughout modern history of the republic of Indonesia, since prior and post amendment of constitutional Law 1945 which known as 2 (two) long term national development planning modeor what so called the General Guidance of State's Pattern (GBHN) and National Long Term Development Plan (RPJPN). The RPJPN model considered as substitute of GBHN implemented in Indonesia's constitutional system after the fourth amendment of constitutional Law 1945 which done from 1999 to 2002. Plannedmodel of National development either in

\footnotetext{
${ }^{9}$ Ibid.

${ }^{10} \mathrm{https}: / /$ www.hukumonline.com/berita/baca/lt5bf133cf4710c/di-era-industri-40--lawyer-berkompetisi-sengit-dengan-ro$\underline{\text { bot }}$

${ }^{11}$ Muhammad Yahya. (2018)Era Revolusi Industri 4.0 : Tantangan dan Peluang Perkembangan Pendidikan Kejuruan Indonesia, Disampaikan pada sidang terbuka luar biasa senat Universitas Negeri Makassar tanggal 14 Maret 2018. p. 6.

${ }^{12}$ Loc.Cit. dikutip dari Sung, T.K, Industri 4.0 : Korea Perspective.Technological Forecasting and Social Change Journal, $\mathrm{p}: 1-6$
} 
the form of GBHN or RPJPN are always contain the substance of all national development aspects including legal development aspect. ${ }^{13}$

GBHN and RPJPN as two models of national development plan in long term are guidelines for national development in every aspect of Indonesia citizen. Those guidelines must be made in the frame of legal state. In other words, policy regarding national development must be made and organized in vivid juridical format. GBHN, for example throughout new order era formalized in the form of provision of People's Consultative Assembly (TAP MPR), meanwhile RPJPN in the reformation era formulized in the form of National law. ${ }^{14}$

Currently, GBHN replacement's document is RPJPN 2005-2025 which formalized through Law number 17 of 2007. Long term National Development Plan of 2005-2025 which further called as National RPJP ${ }^{15}$, is a document of national development plan of 20 years period since 2004 until 2025. It is formulized to be a director as well as guidance for all nation components (government, society and business field) in order to realize national aim and goals in accordance to vision, mission and national direction agreed together so that development attempts can be synergetic, coordinative and completed each other in common attitude and behavior pattern. ${ }^{16}$

Derivative of this document is poured into middle term development plan (RPJM) and document of annual development plan which named Government action plan (RKP). This document is become the basis of the establishment of State's income and expenses budget (APBN). ${ }^{17}$ Detail national development flow can be seen in table below: ${ }^{18}$

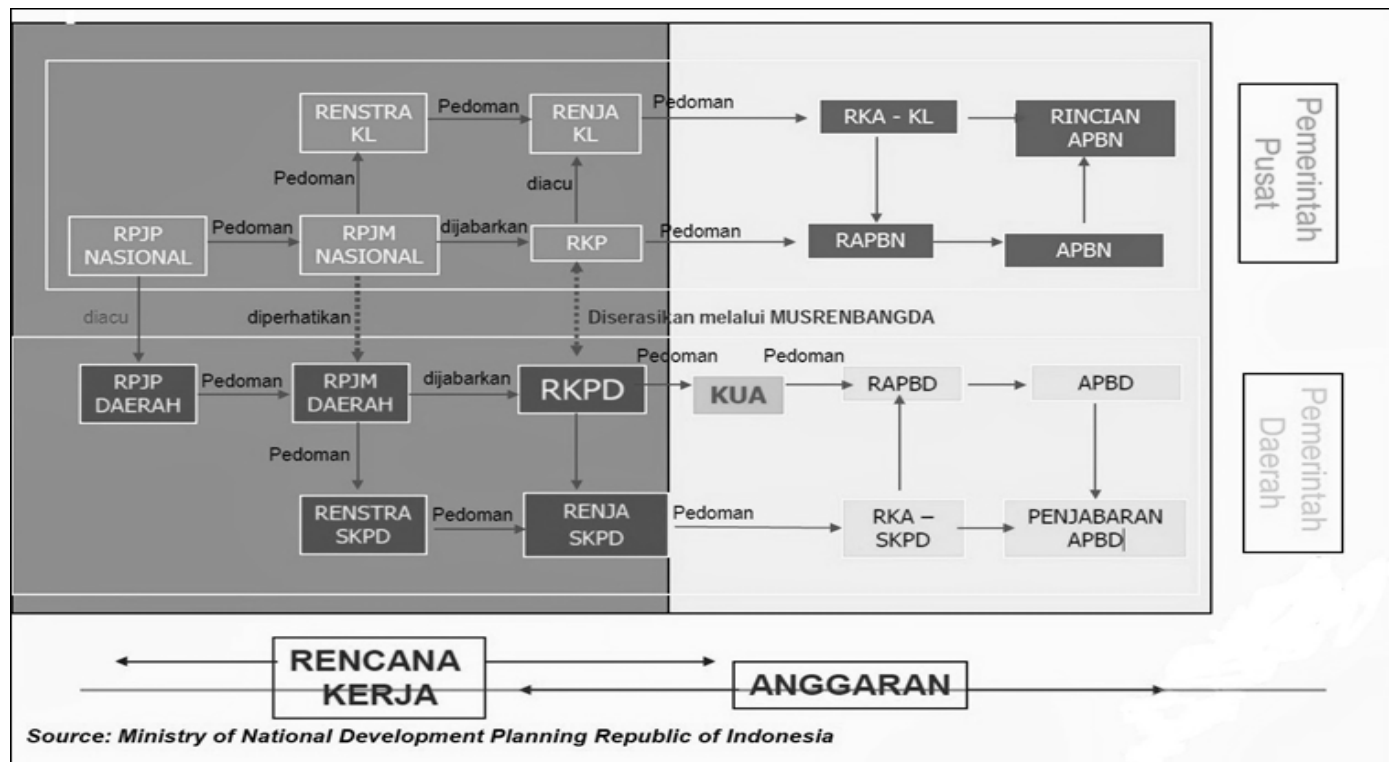

Picture 1.1. Flowchart describing national development plan, Source: Jurnal Aspirasi Vol 5 No. 2 Desember 2014)

\footnotetext{
${ }^{13}$ Syfruddin Muhtamar, Abdul Razak, M Yunus Wahid. (2012). Relevansi Perencanaan Pembangunan Nasional dengan Amanat Konstitusi (Studi Perbandingan Arah Kebijakan Pembangunan Hukum dalam GBHN dan RPJPN. Pasca.Unhas. ac.id/jurnal. Hlm. 4

${ }^{14}$ Ibid. hlm 4

${ }^{15}$ Rencana Pembangunan Jangka Panjang (RPJP) nasional adalah dokumen perencanaan pembangunan nasional yang merupakan jabaran dari tujuan dibentuknya Pemerintahan Negara Indonesia tercantum dalam Pembukaan Undang-Undang Dasar Negara Republik Indonesia Tahun 1945 dalam bentuk visi misi dan arah pembangunan nasional untuk masa 20 tahun ke depan yang mencakupi kurun waktu mulai dari tahun 2005 hingga 2025. Lihat Lampiran Undang-Undang Republik Indonesia Nomor 17 Tahun 2007 Tentang Rencana Pembangunan Jangka Panjang Nasional Tahun 2005-2025.

${ }^{16}$ Imam Subkhan, “GBHN dan Perubahan Perencanaan Pembangunan”.Jurnal Aspirasi Vol 5 No. 2 Desember 2014.Hal 139-140.Lihat: https://jurnal.dpr.go.id/index.php/aspirasi/article/view/455

${ }^{17}$ Ibid.

${ }^{18}$ Ibid.
} 
Conceptually, national vision $2005-2025^{19}$ is constructed and directed to economic development as main prerequisite of national development. The above statement is proven from description of national development 2005-2025 which aimed to direct Indonesia to be independent, developed, fair and prosperous. ${ }^{20}$

In order to be independent, Indonesia require economic development as stated in RPJPN chapter III concerning vision and mission of economic development of 2005-2025 as follows: ${ }^{21}$ (1) "an independent nation is those who are able to realize an equal and parallel standing with other advance nation rely on self-skill and strength. Hence, to build independency, economic development is an ultimate requirement.."; (2) .. development of a nation measured with certain aspects.., including social indicator.., population aspect ... and economic development level..”; (3) "justice and prosperity must be reflected in all aspects of life. Each citizen shared common opportunity to enhance life's well-being; access to job; access to social service, education and health; speak their opinion; carrying out political rights; secure and depend the nation as well as access to protection and equality before the law.

Logical consequences of national vision on economic development also appear in development mission 2005-2025. Five out of eight missions ${ }^{22}$ are related to economic advancement such as (1) strengthening domestic economy; (2) provide economic infrastructure; (3) Harnessing social economy activities; (4) Increase sustainable economic utilization of national resources and environment; (5) build integrated marine economy.

Further, RPJPN 2005-2025 is implemented in 4(four) stages of middle term development plan (RPJM) which formula and policy priority direction can be seen in picture 1.2 below:

\begin{tabular}{|c|c|c|c|}
\hline \multirow{4}{*}{$\begin{array}{l}\text { RPJM } 1 \\
\text { (2005-2009) }\end{array}$} & & & $\begin{array}{l}\text { RPJM } 4 \\
\text { (2020-2024) }\end{array}$ \\
\hline & & $\begin{array}{l}\text { RPJM } 3 \\
\text { (2015-2019) }\end{array}$ & \multirow{4}{*}{$\begin{array}{l}\text { Mewujudkan } \\
\text { masyarakat } \\
\text { Indonesia yg } \\
\text { mandiri, maju, adil } \\
\text { \& makmur mll } \\
\text { percepatan } \\
\text { pembangunan di } \\
\text { segala bidang dg } \\
\text { struktur } \\
\text { perekonomian yg } \\
\text { kokoh } \\
\text { Berlandaskan }\end{array}$} \\
\hline & $\begin{array}{l}\text { RPJM } 2 \\
(2010-2014)\end{array}$ & \multirow{4}{*}{$\begin{array}{l}\text { Memantapkan } \\
\text { pembangunan } \\
\text { secara menyeluruh } \\
\text { dg } \\
\text { menekankan } \\
\text { keunggulan } \\
\text { kompetitif } \\
\text { perekonomian yang } \\
\text { berbasis SDA yg } \\
\text { tersedia, SDM yg } \\
\text { berkualitas, \& } \\
\text { kemampuan iptek }\end{array}$} & \\
\hline & Memantapkan & & \\
\hline \multirow{2}{*}{$\begin{array}{l}\text { Menata kembali } \\
\text { NKRI, membangun } \\
\text { Indonesia yg aman } \\
\text { \& damai, yg adil \& } \\
\text { demokratis, dg } \\
\text { tingkat } \\
\text { kesejahteraan yg } \\
\text { lebih baik. }\end{array}$} & $\begin{array}{l}\text { NKRI, } \\
\text { meningkatkan } \\
\text { kualitas SDM, } \\
\text { membangun } \\
\text { kemampuan iptek, } \\
\text { memperkuat daya }\end{array}$ & & \\
\hline & $\begin{array}{l}\text { saing } \\
\text { perekonomian }\end{array}$ & & $\begin{array}{l}\text { keunggulan } \\
\text { kompetitif. }\end{array}$ \\
\hline
\end{tabular}

Picture 1.2: stages and policy priority scale (Jurnal Aspirasi Vol 5 No. 2 Desember 2014)

\footnotetext{
${ }^{19}$ Rencana Pembangunan Jangka Panjang (RPJP) nasional adalah dokumen perencanaan pembangunan nasional yang merupakan jabaran dari tujuan dibentuknya Pemerintahan Negara Indonesia tercantum dalam Pembukaan Undang-Undang Dasar Negara Republik Indonesia Tahun 1945 dalam bentuk visi misi dan arah pembangunan nasional untuk masa 20 tahun ke depan yang mencakupi kurun waktu mulai dari tahun 2005 hingga 2025.

${ }^{20}$ Op.Cit. Lampiran Undang-Undang Nomor 17 Tahun 2007. p .36-37

${ }^{21}$ Ibid.

22 1) Mewujudkan masyarakat berakhlak mulia, bermoral, beretika,berbudaya, dan beradab berdasarkan falsafah Pancasila; 2)Mewujudkan bangsa yang berdaya saing; 3) Mewujudkan masyarakat demokratis berlandaskan hukum; 4) mewujudkan Indonesia aman, damai, dan bersatu; 5) Mewujudkan pemerataan pembangunan dan berkeadilan; 6) Mewujudkan Indonesia asri dan lestari; 7) Mewujudkan Indonesia menjadi negara kepulauan yang mandiri, maju, kuat, dan berbasiskan kepentingan nasional; 8) Mewujudkan Indonesia berperan penting dalam pergaulan dunia internasional
} 


\section{National Legal Development As Bases Of National Economic}

The effect of economic enhancement spirit as major premise of national development clearly reflected in national law development of RPJPN. In the elaboration of mission, legal development only appears as complementary element and only attached as foundation of 2 (two) national mission out of 8 (eight) existing mission. ${ }^{23}$

Firstly, legal development considered as the foundation of the realization of sustainable economic development. ${ }^{24}$ Legal development is aimed to regulate economic-related issues, provide investment certainty mainly legal enforcement and protection. It is also directed to eradicate the possibility of corruption as well as collusion and nepotism. ${ }^{25}$

Implementation of legal development through legal substance reformation must having regard to existing legal system and globalization effect. It considered as an attempt to increase legal certainty, protection and empowerment as well as Human Rights accomplishment. Legal consciousness and service which based on justice, truth, order and prosperity potentially will lead to a highly competitive state. ${ }^{26}$

Positioned law as the foundation of economic development actually is not a new strategy. In four GBHN of the new order era, legal aspect is un-separately from other aspects such as politic and governance that indicates legal existence is a sub system of national development. It means that legal development is expected to be a substantial proponent of national development process, either in the context of legal drafting, empowerment of officer and legal enforcement.

The above hypothesis concerning legal and economic development is supported by Todung Mulya Lubis as stated in Mahfud MD's book ${ }^{27}$ :

Todung Mulya Lubis for instance, in 1983 has elaborated national legal-politic direction of GBHN. He implicitly declared his approval on social justice based legal development since it formulation shown that legal development must become the tool of economic development legitimation and security. ${ }^{28}$ The above functions enacted in each GBHN of new order era which substantially contained in the expression.. "to ensure the certainty, order, enforcement and legal consideration to support national development.."29

In line with Lubis, Mulyana W Kusumah stated that GBHN formulation prioritized legal instrumental function as an element of dominant political power. It appears from the growth of legal instrument, value and procedure, laws and bureaucracy of legal enforcement which not only reflected legal as circumstances of development process but also become solid basis of politic, economy and social structure. ${ }^{30}$

Opportunity and motivation to carry out a significant legal development in addressing globalization actually has started since GBHN 1993. It formally declared political will of decision maker to positioned law as national sub-system equal to other national sub-system such as politic and economy. The current issue is to translate it to be actual political will y

\footnotetext{
${ }^{23}$ Bandingkan dengan pembangunan ekonomi.

${ }^{24}$ Diatur dalam penjabaran misi ke-2 (dua) "Mewujudkan Bangsa Yang Berdaya Saing"

${ }^{25}$ Op.Cit. Lampiran Undang-Undang Nomor 17 Tahun 2007. p . 57

${ }^{26}$ Ibid.

${ }^{27}$ Mahfud MD, Politik Hukum di Indonesia, PT Raja Grafindo, Jakarta, 2009. p. 19

${ }^{28}$ Todung Mulya Lubis, "Perkembangan Hukum dalam Persspektif Hak Asasi Manusia”. Paper untuk Raker Peradin, November 1983.

${ }^{29}$ Rumusan redaksional didalam setiap GBHN tidak selalu persis seperti ini. Tetapi isinya secara substansial selalu sama. Istilah pembangunan nasional biasanya diidentikan dengan pembangunan ekonomi sebagai titik berat, sehingga mendukung pembangunan nasional dapat diartikan, terutama, mendukung pembangunan ekonomi.

${ }^{30}$ Op.cit. dikutip oleh Mahfud MD dalam : Mulyana W Kusumah (1986)Perspektif, Teori dan Kebijaksanaan Hukum, Rajawali, Jakarta,. p . 29
} 
elaborating it in legal program supported by adequate financing. Thus, well qualified legal science education and implementation is require to play its role in a proportional portion. ${ }^{31}$

Secondly, to realize a democratic Indonesia based on law. Legal development is directed to the realization of a solid national legal system based on Pancasila and Constitutional law 1945. It covers development of legal substance, legal structure including officials, legal infrastructure as an implementation of society's legal awareness and culture in order to implement legal state together with the formation of a fair and democratic society. Legal development carried out through reformation with regard to plurality of legal system and globalization influence as an attempt to increase legal certainty and protection as well as human rights accomplishment. ${ }^{32}$

Development of legal substance is directed to continue legal product renewal ${ }^{33}$ to replace colonial-characterized laws in order to reflect social values and Indonesia's people interest. Further, it also aimed to encourage creativity that involves communities to support governance implementation and national development based on Pancasila and constitutional law 1945 that covers legal planning, formatting, research and development. ${ }^{34}$

Development of legal structure meant to maintain stabilization and effectiveness of various legal organizations, institutions, professions and judicial body so that legal official capable to carry out their duty and obligation professionally. ${ }^{35}$ Quality and skill of legal apparatus developed through quality and professionalism improvement designed in education and training system with accommodative curriculum toward development progress. Attitude development also required to shape legal apparatus who are honest, truthfully, open, fair, free from corruption, collusion and nepotism as well as responsible and integrity. ${ }^{36}$

Implementation and enforcement of law and human rights carried out strictly, straightly, professionally and not discriminative. Most importantly in investigation, examination and trial must be conducted transparently in order to realize social order and discipline to support national stability. ${ }^{37}$ To maintain the territorial unity of the Republic of Indonesia, a sustainable enforcement of see law must be improve in accordance to authority given by national and international law. Strengthening trial body attempted by “one roof” policy of the Supreme Court that sustainably conducting courts development program, judge's quality and professionalism improvement in each court in order to regain public's trust to the court as last fortress of justice seekers. ${ }^{38}$

Public awareness is increased by providing all access to information that required by the community. Public also involved in various processes of decision making and development activities to infused awareness of their rights and obligations as citizens. It resulted,citizen's

${ }^{31}$ Bernard Arief Sidharta. (2000). Refleksi Tentang Struktur Ilmu Hukum (Sebuah penelitian tentang fundasi kefilsafatan dan sifat keilmuan ilmu hukum sebagai landasan pengembangan ilmu hukum Nasional Indonesia).Penerbit Mandar Maju. Bandung.. p 211-212

${ }^{32}$ Op.Cit. Lampiran Undang-Undang Nomor 17 tahun 2007. p. 60

${ }^{33}$ Di sisi lain, perundang-undangan yang baru juga harus mampu mengisi kekurangan/kekosongan hukum sebagai pengarah dinamika lingkungan strategis yang sangat cepat berubah. Perencanaan hukum sebagai bagian dari pembangunan materi hukum harus diselenggarakan dengan memerhatikan berbagai aspek yang memengaruhi, baik di dalam masyarakat sendiri maupun dalam pergaulan masyarakat internasional yang dilakukan secara terpadu dan meliputi semua bidang pembangunan sehingga produk hukum yang dihasilkan dapat memenuhi kebutuhan kehidupan masyarakat, bangsa, dan negara serta dapat mengantisipasi perkembangan zaman.

${ }^{34}$ Ibid.

${ }^{35}$ Aparatur hukum dalam melaksanakan tugas dan kewajibannya secara profesional perlu didukung oleh sarana dan prasarana hukum yang memadai serta diperbaiki kesejahteraannya agar di dalam melaksanakan tugas dan kewajiban aparatur hukum dapat berjalan dengan baik dan terhindar dari pengaruh dan intervensi pihak-pihak dalam bentuk korupsi, kolusi, dan nepotisme.

${ }^{36}$ Ibid.

${ }^{37}$ Penegakan hukum dan hak-hak asasi manusia (HAM) dilakukan terhadap berbagai tindak pidana, terutama yang akibatnya dirasakan angsung oleh masyarakat luas, antara lain tindak pidana korupsi, kerusakan lingkungan, dan penyalahgunaan narkotik.

${ }^{38}$ Ibid. 
attitude that own sense of belonging and legal obedient. The above attempt must be supported with affordable legal service and assistant, efficient process and righteousness verdict making. ${ }^{39}$

To address officer's authority misconduct, good governance principles is applied in all stages, governmental level and activities. Sanction granting to perpetrator of authority misconduct shall be accordingly to straight regulation. On the other side, intensity improvement and supervisor effectiveness of state apparatus is conducted by internal, functional and public supervisory combined with improvement of work ethic and culture as well as improvement knowledge and understanding of the officer toward good governance principle. ${ }^{40}$

According to John Pieris, 4.0 industry revolution's main boosters are Internet and information technology (IT). It has triggered alteration of thinking, working and living pattern of people around the world. However, men shall be positioned as subject of the new civilization based on industry revolution. In the field of law, the option is preserving basic principles of Indonesia while formulating flexible regulation and policy which able to respond changes in the society. ${ }^{41}$

This revolution triggered speedy changes. Therefore John Pieris suggested that people and government of each country must own legal intelligence to respond it. Below is Pieris' detail statement:

"Legal enforcement has always facing issues in every industry revolution. For instance, industry revolution always triggered capital, technology and labour changes. 4.0 industry revolution can influence regulation on copyright, trademark and contract. The law must be able to respond changes, desires and needs of the society (responsive law). However, fundamental legal aspects namely ethic, moral and norm must be reserved by the state, people and government. Meanwhile regulation and policy must be flexible so it can be responsive toward changes and new civilization. ${ }^{42}$ Besides, business actor and government require intelligence in the field of business law, taxation, bank, copyright, contract, cross-country business transaction and law on economic crime. Business actor, government and society must be consistent in implementing legal norm and culture to prevent corruption and other crime.

In my personal view, in carrying out legal development, its planning must include all component of legal system. It means that law is not only developed to support single aspect of life but also must be developed for its own interest. A comprehensive will strengthen legal function as an instrument to provide justice, certainty and benefits of nation's life.

In line with the above statement, Sunaryati Hartono ${ }^{43}$ stated that, the formulation and implementation of legal development can be classified into 15 components as follows:

1) Legal philosophy and principles

2) National legal insight and nurturing approach

3) Legal norms (including jurisprudence and habitual law)

4) Legal systems

5) Legal institutions

6) National legal awareness

7) legal attitude and behavior

8) legal process, procedure, ways and mechanism

9) monitoring, analysis and evaluation, legal study and research

10) Law education system (formal, non-formal and informal)

11) National legal science

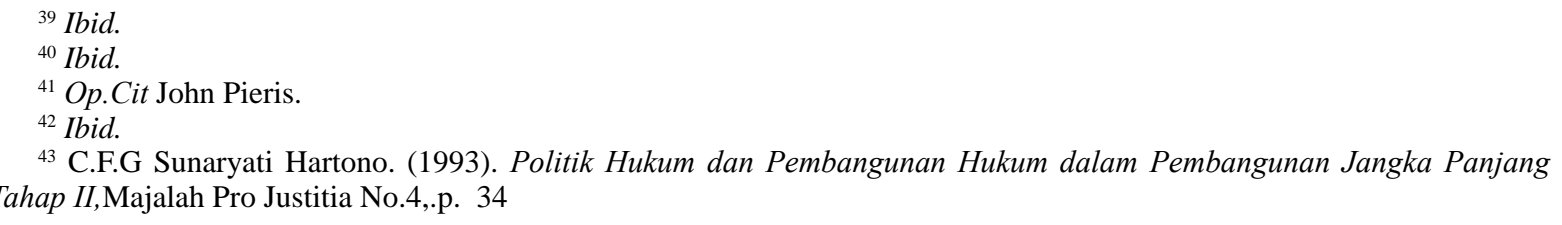


12) Legal profession, legal enforcers and legal service officers

13) Data providing, material, legal reference and information

14) physical and non-physical facilities and infrastructures

15) Legal development plans

Further, legal development design must be address to construct modern national legal system referring to Pancasila's legal aims which provide framework and efficient and responsive regulations for today's and future society order. Such a legal system shall contain below characters:

a) Nationality and archipelago insightful;

b) Able to accommodate legal awareness of local ethnic groups and religious

c) In written and unified form

d) rational; covers efficient-rationality, adequacy-rationality (redelijkheid), norm-rationality and value rationality;

e) procedural regulation that ensure transparency, enable rational analysis on decision making by the government

f) Responsive toward aspiration development and public's aspiration ${ }^{44}$

Beside the above components and characters, legal development also requires continues attempt of legal actors to carrying out ideal legal execution ${ }^{45}$. Legal execution is human's activities related to the existence and application of law in the society. The above activities is including shaping, conducting, applying, finding researching and systematically studying also teaching existing law. It can be divided into practical and theoretical legal execution ${ }^{46}$.

Practical legal execution refers to activities related to legal realization in every day's life concretely. Meanwhile theoretical legal execution covers activities in the field of legal shaping, finding and scientific legal assistant which has methodical-systematic and logic-rational argumentation and well organized..$^{47}$

\section{CONCLUSION}

Overall, it can be concluded that national legal development 2005-2025 was not designed to address 4.0 industry revolution era. Since national legal development direction substantially not (yet) comprehensive and is positioned as economic development cantilever. I d e a l l y legal development designed and constructed in order to address issues in society's life. Substantial pre-condition must be noticed is Pancasila's legal ideals as nation's identity and sustainable attempt to adapt with various dynamics in the era of Industry revolution 4.0.

\section{BIBLIOGRAPHY}

\section{Books}

Bernard AriefSidharta. Mewissententangpengembananhukum, ilmuhukum, teorihukum, danfil safathukum,ReflikaAditama, Bandung, 2008

Bernard Arief Sidharta, Refleksi Tentang Struktur Ilmu Hukum (Sebuah penelitian tentang fundasi kefilsafatan dan sifat keilmuan ilmu hukum sebagai landasan pengembangan ilmu hukum Nasional Indonesia). Penerbit Mandar Maju. Bandung. 2000

\footnotetext{
${ }^{44}$ Op. Cit. Arief Sidharta.

${ }^{45}$ Akar kata perkataan "pengembananhukum” adalah "emban” yangjugaberarrtimenggendong, memikul. Pengembananadalah kata benda; kata kerjanyaadalahmengemban "perkataan "mengemban" di sinidigunakan dal aartimemikulataumenyandangtugasdankewajibanuntukmelaksanakan, menjalankan, mengurus, memelihara, mengolah, danmengembangkansuatujeniskegiatantertentu, dansecara moral bertanggungjawabuntukitu.

46 Bernard AriefSidharta. Meuwissententangpengembananhukum, ilmuhukum, teorihukum, danfilsafathukum, Reflikaaditama,2008. p vii

${ }^{47}$ Ibid
} 
Mahfud MD, Politik Hukum di Indonesia, PT Raja Grafindo, Jakarta, 2009

Mulyana W Kusumah, perspektif, Teori dan Kebijaksanaan hukum, Rajawali, Jakarta, 1986.

Satcipto rahardjo, Ilmu Hukum, PT Citra Aditya Bakti, cetakan kedelapan, Bandung, 2014.

\section{Journal articles:}

C.F.G Sunaryati Hartono, Politik Hukum dan Pembangunan Hukum dalam Pembangunan Jangka Panjang Tahap II,Majalah Pro Justitia No.4, 1993

Imam Subkhan, GBHN dan Perubahan Perencanaan Pembangunan.Jurnal Aspirasi Vol 5 No. 2 Desember 2014.

Syfruddin Muhtamar, Abdul Razak, M Yunus Wahid. 2012. Relevansi Perencanaan Pembangunan Nasional dengan Amanat Konstitusi (Studi Perbandingan Arah Kebijakan Pembangunan Hukum dalam GBHN dan RPJPN. Pasca.Unhas.ac.id/jurnal

Todung Mulya Lubis, “Perkembangan Hukum dalam Persspektif Hak Asasi Manusia”. Paper untuk Raker Peradin, November 1983

Venti Eka Satya, Strategi Indonesia Menghadapi Industri 4.0,Info Singkat Vol. X No. 9/I/ Puslit/Mei/2018, Pusat Penelitian Badan Keahlian DPR-RI, Jakarta, 2018

World Wide Web:

http://www.stagingpoint.com/read/2018/11/14/151205/Kecerdasan.Hukum.Respons. Revolusi.Industri.4.0

https://www.hukumonline.com/berita/baca/1t5bf133cf4710c/di-era-industri-40--lawyerberkompetisi-sengit-dengan-robot

https://jurnal.dpr.go.id/index.php/aspirasi/article/view/455

\section{Regulation}

Undang-Undang Nomor 17 Tahun 2007 Tentang Rencana Jangka Panjang Nasional 